\title{
Performance Evaluation of Various Photovoltaic Module Technologies at Nawabshah Pakistan
}

\author{
Abdul Rehman Jatoi, Saleem Raza Samo, Abdul Qayoom Jakhrani*
}

\author{
Energy and Environment Engineering Department, Quaid-e-Awam University of Engineering, Science and Technology, Nawabshah, \\ 67480, Sindh, Pakistan
}

\begin{abstract}
The purpose of this study was to evaluate the influence of module temperature on the efficiency of polycrystalline (p-Si), monocrystalline (m-Si), amorphous (a-Si) and thin film photovoltaic modules at the outdoor environment of Nawabshah city Pakistan. The experimental setup was made and installed over the top roof of departmental building. Weather conditions, such as global solar radiation, ambient temperature, wind speed and relative humidity; power output and temperature of all selected four types of module technologies were measured at the site by logging data. Then, the power output of the modules was normalized because of different rated power of photovoltaic modules for comparison purpose. Results revealed that less temperature impact was noted from thin film module and thus it gave more normalized power with $45.6 \%$ among other examined modules. On the basis of overall efficiency, $\mathrm{p}$-Si, $\mathrm{m}-\mathrm{Si}$, a-Si and thin film modules gave $92.4 \%, 93.7 \%, 94.4 \%$ and $95.4 \%$ yearly average normalized efficiencies respectively. It was found that temperature has more impact on the efficiency of other examined modules compared to thin film modules. Thus, it is concluded from the study that thin film module is better at the outdoor environment of Nawabshah.
\end{abstract}

Keywords: weather conditions, normalized power output, module temperature, temperature coefficients, efficiency of photovoltaic modules

Article History: Received: 20th August 2020; Revised: 12 $2^{\text {th }}$ October 2020; Accepted: 21 st Oct 2020; Available online: 29th Oct 2020

How to Cite This Article: Jatoi, A.R., Samo, S.R., and Jakhrani, A.Q. (2021) Performance Evaluation of Various Photovoltaic Module Technologies at Nawabshah Pakistan. International Journal of Renewable Energy Development, 10(1), 97-103

https://doi.org/10.14710/ijred.2021.32352

\section{Introduction}

The efficiency of commercial polycrystalline ( $p-\mathrm{Si})$ cell is around 12-13\%, monocrystalline (m-Si) $14-15 \%$ and amorphous (a-Si) 6-7\% at STC (Kalogirou 2014). Photovoltaic (PV) modules give maximum power output at STC (Duffie and Beckman 2013; Kalogirou 2014; Jakhrani et al. 2014). Meanwhile these conditions are hardly prevailing at outdoor environments (Schwingshackl et al. 2013; Ali et al. 2017). Still, some factors affect the power of PV modules, such as solar radiation, ambient temperature, cell temperature, tilt angle, shading, cell materials (Jatoi et al. 2018; Lee et al. 2011; Hasan and Sumathy 2010; Coskun et al. 2017; Malik and Chandel 2020) and dust deposition (Tripathi et al. 2017). These factors alone as well as in combination with each other affect the efficiency of photovoltaic modules (Coskun et al. 2017). The power output of modules decreased due to less solar radiation and maximum temperature gained by photovoltaic module at outdoor conditions (Maghami et al. 2016). After solar radiation, module temperature is one of the major factors that adversely affect the power of PV modules (Jatoi et al. 2018; Duffie and Beckman 2013; Kalogirou 2014; Jakhrani et al. 2014).

The PV module temperature coefficients reported by different researchers and manufacturers for polycrystalline modules were minus $0.40 \% /{ }^{\circ} \mathrm{C}$ (King et al.
2002) and $0.64 \% /{ }^{\circ} \mathrm{C}$ (Perraki and Kounavis 2016). Whereas, for monocrystalline modules were minus 0.39 $\% /{ }^{\circ} \mathrm{C}$ (Perraki and Kounavis 2016) and $0.50 \% /{ }^{\circ} \mathrm{C}$ (King et al. 2002). Similarly, for amorphous modules were minus $0.10 \% /{ }^{\circ} \mathrm{C}$ (Gaur and Tiwari 2014) and $0.25 \% /{ }^{\circ} \mathrm{C}$ (King et al. 2002), and for thin module was minus $0.24 \% /{ }^{\circ} \mathrm{C}$ (Clean Energy Project Analysis 2004).

Increase of PV module temperature lowers the power output of cell or module (Jatoi et al. 2018; Duffie and Beckman 2013; Jakhrani et al. 2012; Jatoi et al. 2016). Akhmad et al. (1997) investigated the performance of different cell technologies in outdoor condition and found that amorphous has better performance than polycrystalline in summer months. Jatoi et al. (2018) revealed that amorphous (single junction) photovoltaic module produces $5.7 \%, 2.7 \%$ and $15.0 \%$ more yearly average open-circuit voltage $\left(\mathrm{V}_{\text {oc }}\right)$ than $\mathrm{p}-\mathrm{Si}, \mathrm{m}-\mathrm{Si}$ and thin film modules at outdoor condition of Nawabshah. Bashir et al. (2015) reported that the monocrystalline module was more efficient with $13.5 \%$ than polycrystalline and amorphous modules in Taxila, Pakistan. Ali et al. (2017) noted that monocrystalline module gave $11.4 \%$ efficiency which was higher than the other studied modules in summer months. Milosavljevic et al. (2015) revealed that the increase of $1{ }^{\circ} \mathrm{C}$ in ambient temperature, decreases $0.3 \%$ of monocrystalline module efficiency. Harijan et al.

\footnotetext{
*Corresponding author: aqunimas@hotmail.com, arjatoi@quest.edu.pk
} 
(2015) concludes that annually 455.3 GWh of electricity could be generated Pakistan from standalone PV systems. The reduction of $22 \%, 16 \%$ and $18 \%$ of average power is noted in June, July and August months due to accumulation of dust on the surface of PV modules by Abbas et al. (2017). Besides that, the overall 3\% power reduction was noted for $\mathrm{p}$-Si module after three months of environmental exposure. Mekhilef et al (2012) examined the influence of humidity, dust accumulation and air velocity, and concluded that the effect of each influencing parameter is not an easy task and should not be considered separately.

It is a fact that the indoor (controlled) conditions are totally different than that of outdoor conditions due to unlike atmospheric and topographic conditions of the locations. Therefore, this study was conducted to compare the daily average power output of different photovoltaic modules in actual environmental conditions and to analyze the impact of module temperature on the efficiency of photovoltaic modules at outdoor conditions of Nawabshah, Sindh, Pakistan.

\section{Methodology}

\subsection{Experimental setup}

In this work, the performance of four PV module technologies, viz; p-Si, m-Si, a-Si and thin film were examined. Three of them ( $\mathrm{p}-\mathrm{Si}, \mathrm{m}-\mathrm{Si}$ and a-Si) were of $40 \mathrm{~W}$ rated power, and only thin film was of 50W (Jatoi et al. 2016). The system was mounted towards true south at a slope of $12^{\circ}$ over the roof top of departmental building at QUEST Nawabshah, Sindh, Pakistan. The installed PV system is shown in Figure 1.

\subsection{Data logging}

One-year data of weather conditions, photovoltaic power output and module temperature were recorded and considered for analysis. Weather parameters, such as $G_{s r}$, $T_{a}, W_{v}$ and $R_{h}$ were measured with HP-2000, power output of PV modules with Prova-210 and the module temperature with Prova-830 data logger. All system components were interconnected with computer for analysis and interpretation of data. PV modules were cleaned early in the morning before data recording.

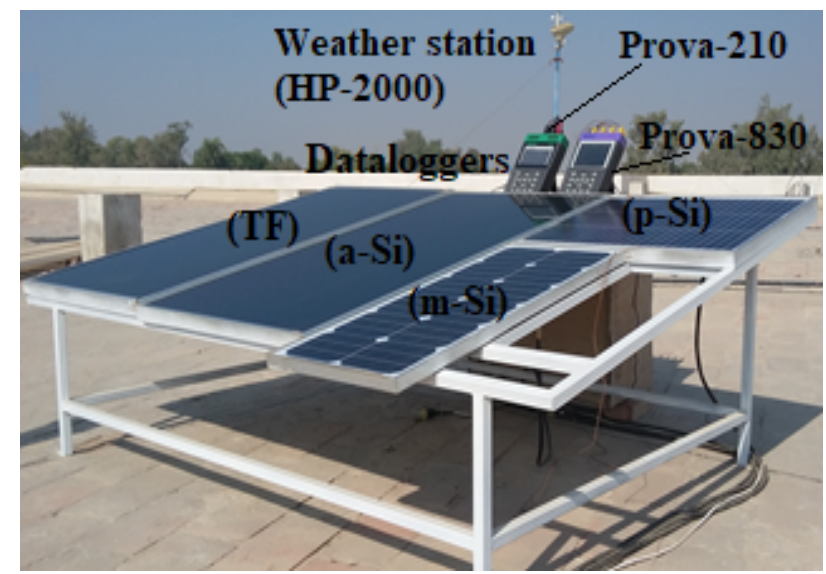

Fig. 1 Experimental setup

\subsection{Normalized power output of modules}

In this section, the PV power output was normalized due to their unequal rated power output. As three PV modules have rated power of $40 \mathrm{~W}$ (p-Si, m-Si and a-Si) and only thin film was of $50 \mathrm{~W}$. Therefore, the equation (1) was used to normalize the measured power output of each photovoltaic module for the purpose of comparison and performance analysis. This methodology was followed as reported by (Bashir et al. 2014; Jatoi et al. 2019).

$$
P_{n}=\left(\frac{P_{\max }}{P_{\max -S T C}}\right) \times 100
$$

where, $P_{n}, P_{\max }$ and $P_{\max -S T C}$ are the normalized power output of modules, measured maximum power output of modules in actual condition (outdoor) and power output of module at STC.

\subsection{Estimation of photovoltaic modules efficiency}

For photovoltaic modules efficiency, the basic equation (2) is used for computing the impact of module temperature on the efficiency of each photovoltaic module. The equation was used by most researchers with some variation (Skoplaki and Palyvos 2009; Evans 1981).

$$
\eta_{m}=\eta_{m-S T C}\left[1-\mu_{m}\left(T_{m}-T_{m-S T C}\right)\right]
$$

where, $\eta_{m}, \eta_{m-S T C}, \mu_{m}, T_{m}$ and $T_{m-S T C}$ are the efficiency of PV modules, efficiency of PV modules at STC, temperature coefficient, measured module temperature and module temperature at STC.

For solving the equation (2), the temperature coefficient $\left(\mu_{m}\right)$ and module temperature $\left(T_{m}\right)$ were the main parameters. For that, different power bins were made with global solar radiations of $1000 \mathrm{~W} / \mathrm{m}^{2}$ and module temperature of $50^{\circ} \mathrm{C}$ to $70^{\circ} \mathrm{C}$ as reported by Yusoff et al. (2016), Technical brief (2017), Wilcox (2012), Field and Gabor (2002), Assoa et al. (2018), and Cebecauer et al. (2011) with consideration of $\pm 5 \mathrm{~W} / \mathrm{m}^{2}$ in radiation and $\pm 0.5^{\circ} \mathrm{C}$ in module temperature. The details are available in Jatoi et al. (2019).

Furthermore, photovoltaic module temperature coefficients $\left(\mu_{m}\right)$ were estimated using equation (3) as reported by (Shaari et al. 2009; Malik et al. 2010).

$$
\mu_{m}=\left(\frac{P_{\max }-P_{S T C}}{T_{m}-T_{S T C}}\right)
$$

where, $\mu_{m}, P_{\max }, P_{S T C}, T_{m}$ and $T_{S T C}$ are the temperature coefficient, measured maximum power output of module, power output of module at STC, measured module temperature and module temperature at STC respectively. 


\section{Results and Discussion}

\subsection{Weather conditions}

Four important weather parameters, namely daily average measured data of global solar radiation $\left(G_{s r}\right)$, ambient temperature $\left(T_{a}\right)$, wind speed $\left(W_{v}\right)$ and relative humidity $\left(R_{h}\right)$ were considered in this study and plotted in Figures 2-5. Figure 2 displays the daily average values of $\mathrm{G}_{\text {sr. }}$ The maximum $\mathrm{G}_{\mathrm{sr}}$ was found $1125 \mathrm{~W} / \mathrm{m}^{2}$ in June. Whereas, maximum and minimum daily average values of $\mathrm{G}_{\text {sr }}$ were noted with $756.98 \mathrm{~W} / \mathrm{m}^{2}$ and $239.86 \mathrm{~W} / \mathrm{m}^{2}$. On yearly average basis, $\mathrm{G}_{\text {sr }}$ was $0.5184 \mathrm{k} \mathrm{W} / \mathrm{m}^{2}$ during study period. The daily average $\mathrm{T}_{\mathrm{a}}$ for the similar time period is depicted in Figure 3. The maximum $\mathrm{T}_{\mathrm{a}}$ was observed $49.2^{\circ} \mathrm{C}$ in June. While, minimum to maximum range of daily average $\mathrm{T}_{\mathrm{a}}$ were found $15.58^{\circ} \mathrm{C}$ to $41.12^{\circ} \mathrm{C}$, although its yearly average was noted as $30.10^{\circ} \mathrm{C}$. Similarly, the daily average $\mathrm{W}_{\mathrm{v}}$ for the similar time period are summarized in Figure 4. The maximum gust of $\mathrm{W}_{\mathrm{v}}$ was recorded $15.7 \mathrm{~m} / \mathrm{s}$ in January. On daily average basis, the maximum $\mathrm{W}_{\mathrm{v}}$ was recorded as $6.14 \mathrm{~m} / \mathrm{s}$ and minimum with $0.33 \mathrm{~m} / \mathrm{s}$ with yearly average of $2.13 \mathrm{~m} / \mathrm{s}$. Figure 5 illustrated the daily average of $\mathrm{R}_{\mathrm{h}}$ data. The minimum to maximum range of daily average $R_{h}$ was $11.33 \%$ and $70.16 \%$ respectively. Moreover, the yearly average value of $R_{h}$ was noted as $42.66 \%$.

It was discovered from results that maximum daily average of $\mathrm{G}_{\mathrm{sr}}$ and $\mathrm{T}_{\mathrm{a}}$ were observed in June and wind gust in the month of January. Maximum $R_{h}$ was noted in January and minimum in May. It is revealed that January month is calm and May \& June months are the hottest. It was found from analysis, that $\mathrm{G}_{\mathrm{sr}}$ and $\mathrm{T}_{\mathrm{a}}$ were rising from morning till noon, and then falling slowly in the evening. The maximum $R_{h}$ was noted when $G_{s r}$ and $T_{a}$ were low, and vice versa.

\subsection{Normalized power of photovoltaic modules}

The rated power output of the examined PV modules was not same. Therefore, the power output of modules was normalized for the comparative analysis and discussed as yearly average basis.

In Figure 6, the comparison of daily average normalized power output of all four examined modules is depicted. It was found that $\mathrm{p}-\mathrm{Si}, \mathrm{m}-\mathrm{Si}, \mathrm{a}-\mathrm{Si}$ and thin film modules gave $55.31 \%, 54.24 \%, 49.45 \%$ and $60.43 \%$ of maximum daily average normalized power of their rated power in June. Whereas, the minimum daily average normalized power output was noted from polycrystalline with $14.24 \%$, monocrystalline with $13.67 \%$, amorphous with $12.69 \%$ and thin film with $16.81 \%$ in January.

It was found that $\mathrm{p}-\mathrm{Si}$ module produced $43.97 \%$, mSi $41.61 \%$, a-Si $36.78 \%$ and thin film $45.61 \%$ yearly average normalized (maximum) power output as illustrate in Table 1.

In the comparison of crystalline and noncrystalline photovoltaic modules, the p-Si gave 2.36 more percentage of normalized power than m-Si. Similarly, the thin film generates 8.82 more percentage of normalized power than a-Si.

In over all, thin film produced 1.64, 4.00 and 8.82 more percentage of average normalized power output than $\mathrm{p}$-Si, $\mathrm{m}$-Si and a-Si modules. It is discovered from analysis that the polycrystalline module gave maximum daily average normalized power than other PV modules from
December to February months and thin film from March to October months than other modules. The output trend of polycrystalline and monocrystalline were found close to each other. It is revealed that the performance of thin film module was best among the examined modules on yearly average basis. If the mounting space is no limits, the thin film module technologies are the best option as others because it gives maximum performance in hot months than calm months.

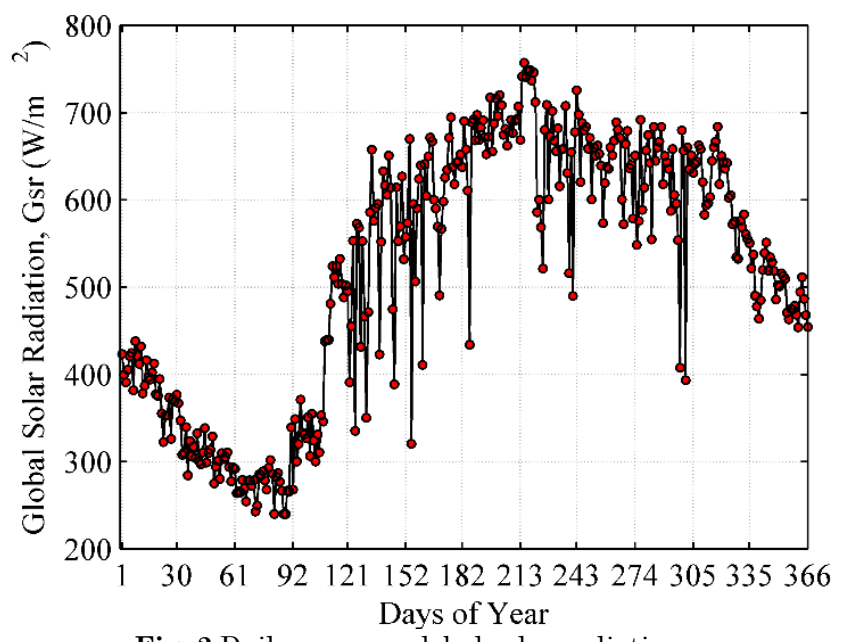

Fig. 2 Daily average global solar radiations.

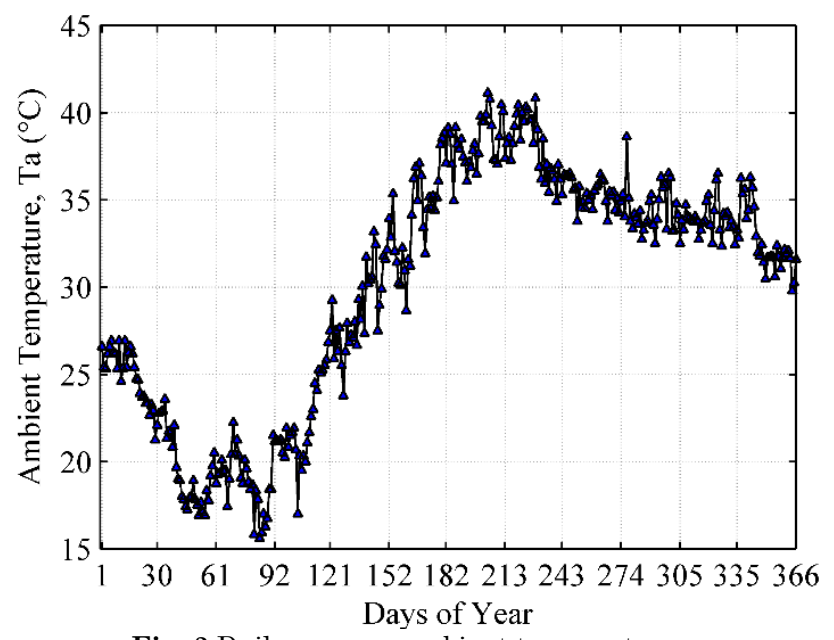

Fig. 3 Daily average ambient temperature.

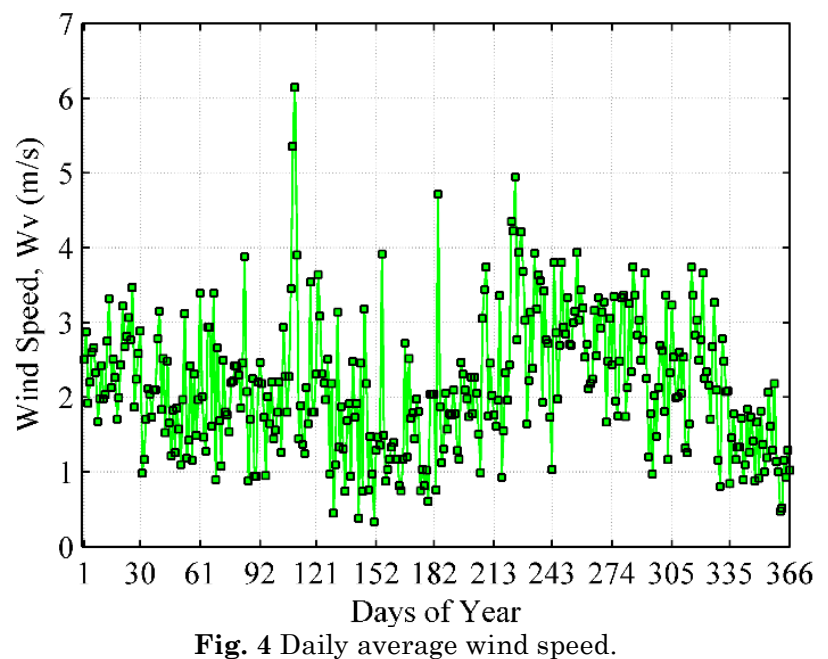

Fig. 4 Daily average wind speed. 

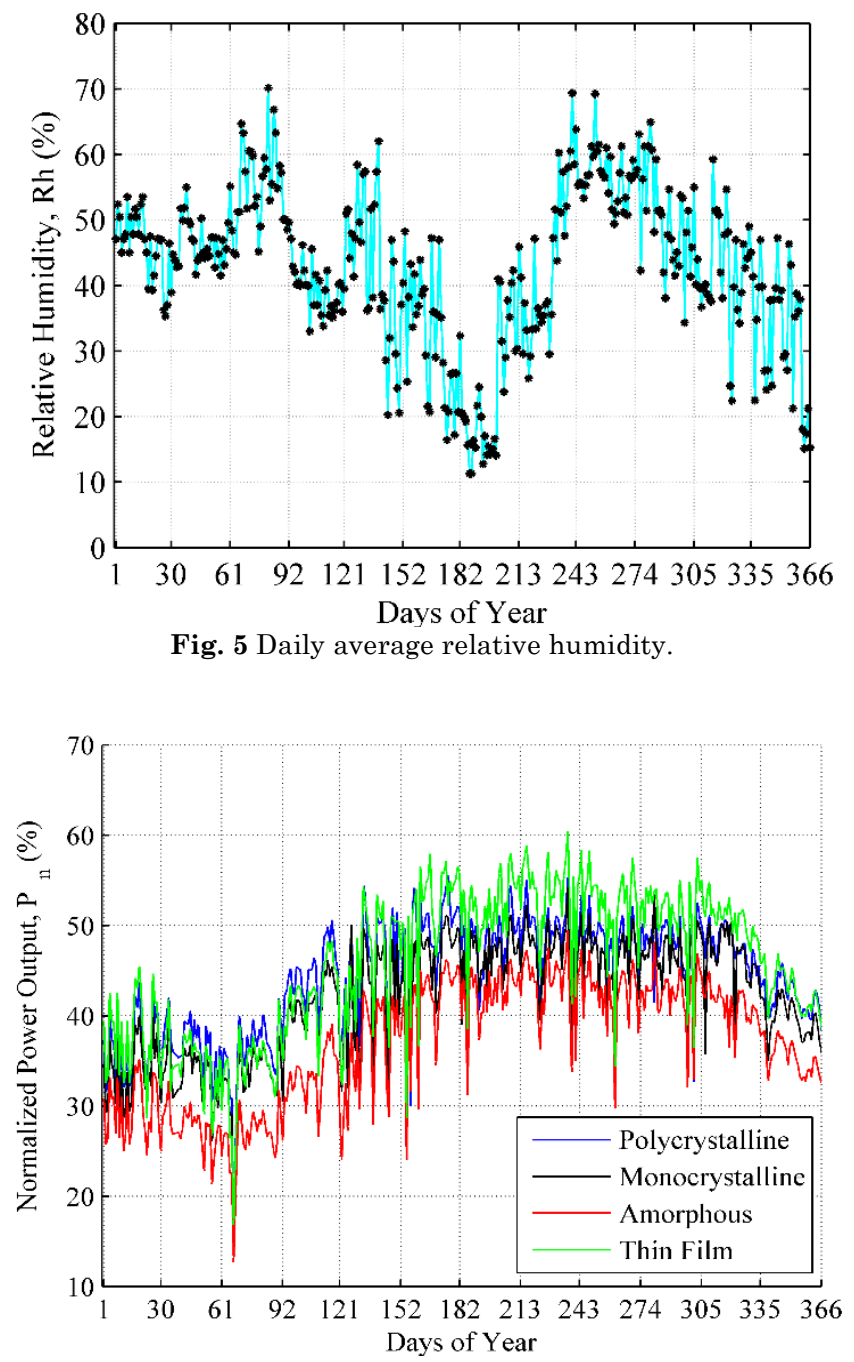

Fig. 6 Daily average normalized power.

Table 1

Yearly average normalized power output

\begin{tabular}{lcccc} 
& \multicolumn{4}{c}{ Photovoltaic module technologies } \\
\cline { 2 - 5 } & $\mathrm{p}-\mathrm{Si}$ & $\mathrm{m}-\mathrm{Si}$ & $\mathrm{a}-\mathrm{Si}$ & $\begin{array}{c}\text { Thin } \\
\text { Film }\end{array}$ \\
\hline $\begin{array}{l}\text { Rated power (W) } \\
\begin{array}{l}\text { Yearly average } \\
\text { normalized power } \\
\text { output (\%) }\end{array}\end{array}$ & 40 & 40 & 40 & 50 \\
\hline
\end{tabular}

\subsection{Module temperature}

Figure 7 represents the daily average measured module temperature $\left(T_{m}\right)$ of the studied modules. The minimum and maximum daily average measured module temperature of $\mathrm{p}-\mathrm{Si}, \mathrm{m}-\mathrm{Si}, \mathrm{a}-\mathrm{Si}$ and thin film were noted as $28.20^{\circ} \mathrm{C}$ and $57.85^{\circ} \mathrm{C}, 27.45^{\circ} \mathrm{C}$ and $56.82^{\circ} \mathrm{C}, 28.17^{\circ} \mathrm{C}$ and $58.07^{\circ} \mathrm{C}$, and $27.77^{\circ} \mathrm{C}$ and $58.83^{\circ} \mathrm{C}$ respectively. While the yearly average $\mathrm{T}_{\mathrm{m}}$ of $\mathrm{p}-\mathrm{Si}, \mathrm{m}-\mathrm{Si}$, a-Si and thin film were found as $43.96^{\circ} \mathrm{C}, \quad 43.45^{\circ} \mathrm{C}, \quad 44.29^{\circ} \mathrm{C}$ and $43.55^{\circ} \mathrm{C}$ respectively. The minimum module temperature was observed in the month of January and maximum in May and June.

In comparison of crystalline photovoltaic modules, the $\mathrm{p}$-Si module gained $0.5^{\circ} \mathrm{C}$ more yearly average temperature than $\mathrm{m}-\mathrm{Si}$ and in noncrystalline modules. a-
Si attained $0.4^{\circ} \mathrm{C}$ more module temperature than thin film module. In overall, it was observed that p-Si, m-Si and thin film module attain $0.3^{\circ} \mathrm{C}, 0.8^{\circ} \mathrm{C}$ and $0.7^{\circ} \mathrm{C}$ less yearly average temperatures than a-Si modules respectively.

It was observed from comparison for temperature accomplishment that a-Si module achieved more temperature than other modules. It was deduced that all studied modules attain less temperature from DecemberJanuary (calm months) and maximum temperature from May-June (hottest months). It was revealed that modules accomplished and released temperature slowly and gradually throughout the studied period.

\subsection{Obtained module temperature coefficients}

The trend of temperature coefficients $(\mu)$ versus module temperature is presented in Figure 8. The average temperature coefficients of $\mathrm{p}-\mathrm{Si}, \mathrm{m}-\mathrm{Si}, \mathrm{a}-\mathrm{Si}$ and thin film were found as $-0.40,-0.34,-0.29$ and -0.25 percentage per degree centigrade respectively. It was observed that crystalline PV modules have maximum effect of module temperature than noncrystalline PV modules due to composition and characteristics of their material.

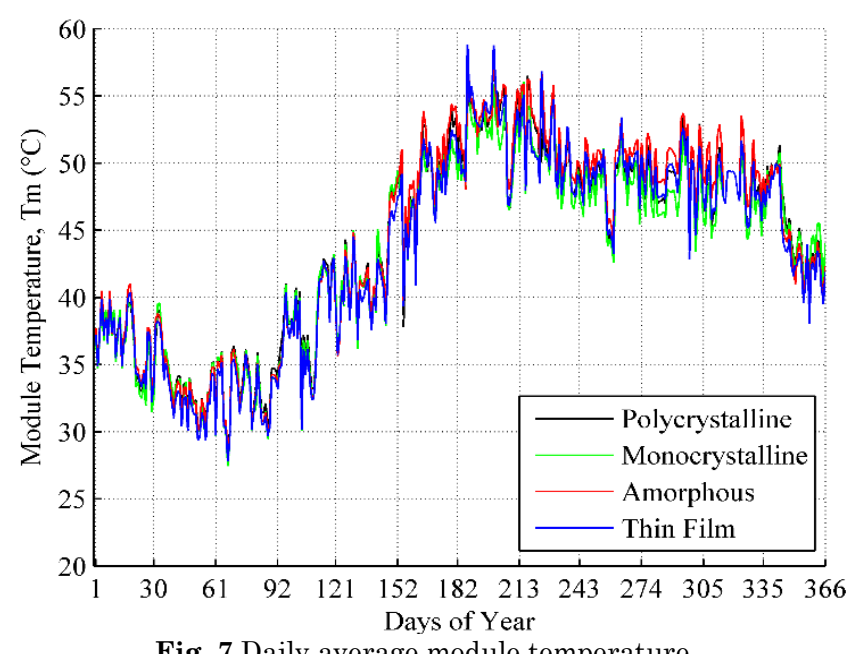

Fig. 7 Daily average module temperature.

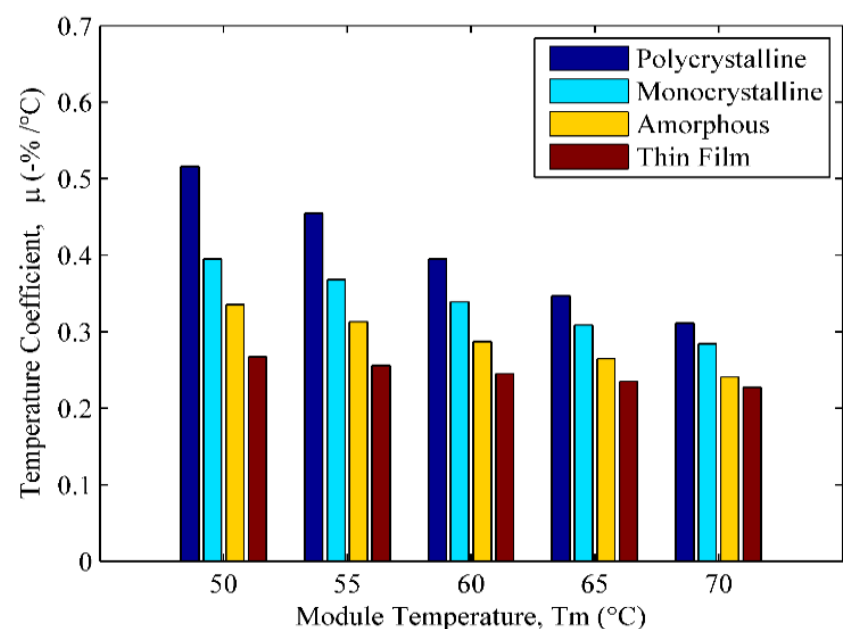

Fig. 8 Module temperature coefficients. 


\subsection{Effect of module temperature on the efficiency of $P V$ modules}

Figure 9 illustrates the daily average efficiency of crystalline (polycrystalline and monocrystalline) modules. The highest daily average reduction of polycrystalline module efficiency was noted as $1.91 \%$ and minimum with $0.18 \%$ when daily average module temperature was $57.85^{\circ} \mathrm{C}$ and $28.21^{\circ} \mathrm{C}$ respectively. Since, the average polycrystalline module efficiency was found $1.1 \%$ less from its rated efficiency of $14.6 \%$ when average module temperature was $43.96^{\circ} \mathrm{C}$. Similarly, the maximum daily average reduction of monocrystalline module efficiency was noted as $1.78 \%$ and minimum as $0.13 \%$ when the daily average module temperature was $56.83^{\circ} \mathrm{C}$ and $27.45^{\circ} \mathrm{C}$ respectively. Since, the yearly average monocrystalline module efficiency reduction was found $1.04 \%$ from its rated efficiency $16.50 \%$ when average module temperature was $43.46^{\circ} \mathrm{C}$.

The daily average efficiency of non-crystalline (amorphous and thin film) modules are illustrated in Figure 10. The maximum daily average reduction of amorphous module efficiency was noted as $0.50 \%$ and minimum as $0.04 \%$ when module the temperature was $58.07^{\circ} \mathrm{C}$ and $25.12^{\circ} \mathrm{C}$ respectively. Yearly average amorphous module efficiency reduction was found $0.30 \%$ from its rated efficiency of $5.30 \%$ when the average module temperature was $44.29^{\circ} \mathrm{C}$. Besides that, the highest daily average reduction efficiency of thin film module efficiency was recorded as $0.67 \%$ and minimum as $0.15 \%$ when module temperature was $58.83^{\circ} \mathrm{C}$ and $27.77^{\circ} \mathrm{C}$ respectively. Yearly average efficiency reduction of thin film module was noted as $0.31 \%$ from its rated efficiency of $6.70 \%$ when the average module temperature was $43.55^{\circ} \mathrm{C}$

It was revealed that the minimum reduction of all examined module's efficiency was noted in December and January months due to unperturbed months. Maximum efficiency reduction was observed in May and June months. Besides that, the overall reduction trend in efficiency were recorded from April to October because these months were found hottest months. Furthermore, it was observed that the increment and decrement in efficiency of examined modules was depends on the module temperature and material properties and vice versa.

Polycrystalline (p-Si), m-Si, a-Si and thin film modules gave 92.4\%, 93.7\%, 94.4\% and 95.4\% yearly average normalized efficiencies respectively as shown in Table 2. Among all modules, thin film module demonstrated maximum yearly average normalized efficiency in actual atmospheric conditions.

Table 2

Electrical efficiencies of studied PV modules

\begin{tabular}{lcccc}
\hline \multirow{2}{*}{ Efficiency } & \multicolumn{4}{c}{ Photovoltaic module technologies } \\
\cline { 2 - 5 } & $\mathrm{p}-\mathrm{Si}$ & $\mathrm{m}-\mathrm{Si}$ & $\mathrm{a}-\mathrm{Si}$ & $\begin{array}{c}\text { Thin } \\
\text { Film }\end{array}$ \\
\hline $\begin{array}{l}\text { Rated efficiency (\%) } \\
\text { Yearly average } \\
\text { efficiency output (\%) }\end{array}$ & 14.6 & 16.5 & 5.3 & 6.7 \\
$\begin{array}{l}\text { Yearly average } \\
\text { normalized efficiency } \\
(\%)\end{array}$ & 92.4 & 15.46 & 5.00 & 6.39 \\
\hline
\end{tabular}

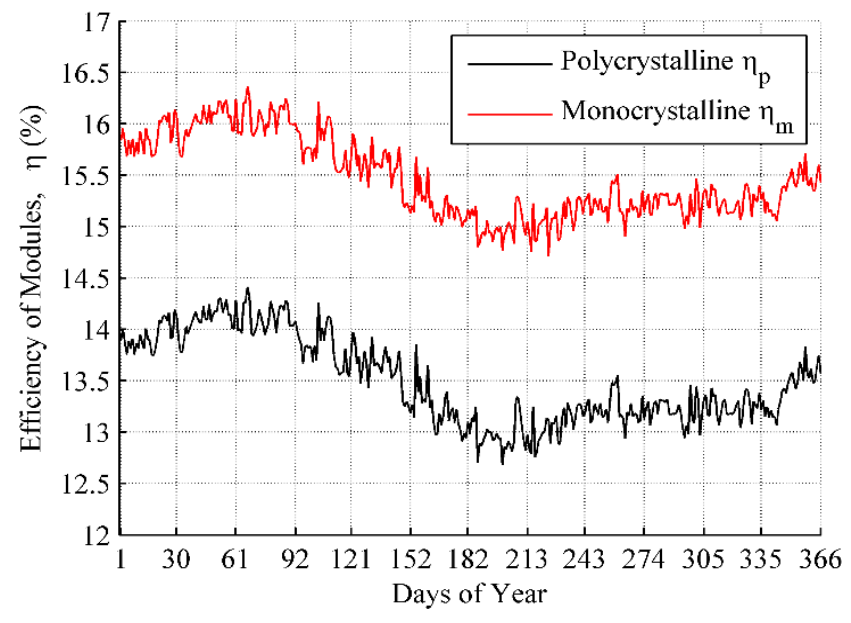

Fig. 9 Efficiency of crystalline photovoltaic modules versus time (days).

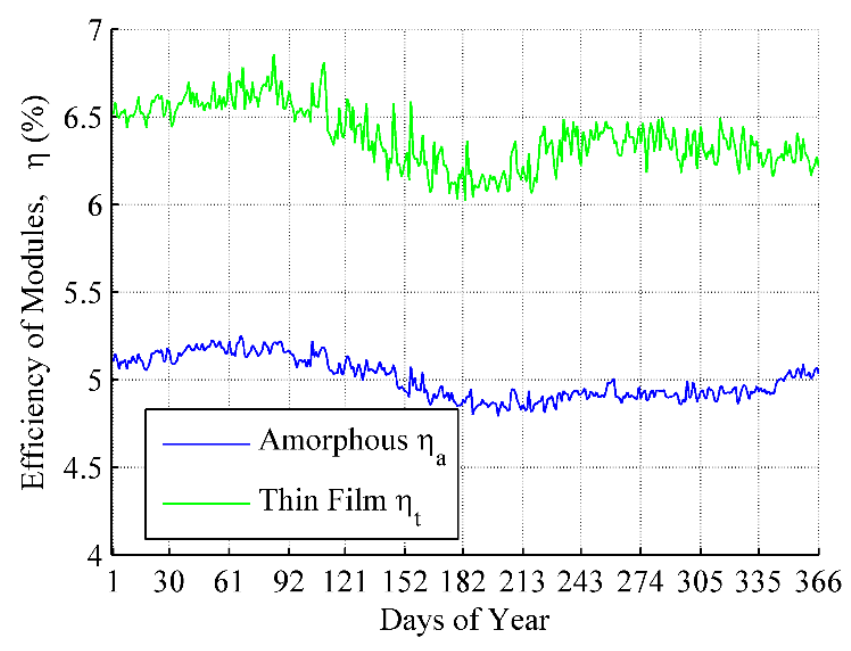

Fig. 10 Efficiency of non-crystalline photovoltaic modules versus time (days).

If there is enough space for mounting and installation of modules, then thin film module technologies could be the best option in hot climatic areas. The main cause of temperature increase of modules was higher radiations at noon, thus the power out of modules became lower due to negative impact of module temperature versus power output.

\section{Conclusion}

Maximum daily average values of global solar radiation were noted as $756.98 \mathrm{~W} / \mathrm{m}^{2}$, ambient temperature $41.12^{\circ} \mathrm{C}$, wind velocity $6.14 \mathrm{~m} / \mathrm{s}$ and relative humidity $70.16 \%$ during study period.

It was found that $\mathrm{p}-\mathrm{Si}, \mathrm{m}-\mathrm{Si}, \mathrm{a}-\mathrm{Si}$ and thin film modules produced $43.97 \%, 41.61 \%, 36.78 \%$ and $45.61 \%$ yearly average normalized power output. It is concluded that the performance of thin film module was relatively excellent among the examined modules on yearly average basis. The output trend of polycrystalline and monocrystalline were found close to each other.

Yearly average module temperature of $\mathrm{p}-\mathrm{Si}, \mathrm{m}-\mathrm{Si}, \mathrm{a}-\mathrm{Si}$ and thin film was found $43.96^{\circ} \mathrm{C}, 43.45^{\circ} \mathrm{C}, 44.29^{\circ} \mathrm{C}$ and 
$43.55^{\circ} \mathrm{C}$ respectively. It was discovered that amorphous module attains $0.3^{\circ} \mathrm{C}, 0.8^{\circ} \mathrm{C}$ and $0.7^{\circ} \mathrm{C}$ more yearly average temperatures than $\mathrm{p}-\mathrm{Si}, \mathrm{m}-\mathrm{Si}$ and thin film modules respectively. The attainment and release of module temperature may be associated with the material properties of PV module technologies.

The average temperature coefficient for polycrystalline, monocrystalline, amorphous and thin film module was calculated as $-0.40 \% /{ }^{\circ} \mathrm{C},-0.34 \% /{ }^{\circ} \mathrm{C},-0.29$ $\% /{ }^{\circ} \mathrm{C}$ and $-0.25 \% /{ }^{\circ} \mathrm{C}$ respectively. On the basis of yearly average normalized efficiency, p-Si, m-Si, a-Si and thin film modules showed 92.41, 93.72, 94.40 and 95.37 yearly average normalized efficiencies of their rated efficiencies.

It is concluded from the study that the temperature has more impact on the efficiency of polycrystalline, monocrystalline and amorphous than that of thin film. It was revealed that the minimum reduction of modules efficiency was noted in December and January months due to unperturbed months, whereas, the maximum efficiency reduction was observed in the months of May and June. Besides that, the overall reduction trend in efficiency was recorded from April to October because these months were found hottest. Furthermore, it was observed that the increment and decrement in efficiency of examined modules depends on their material properties.

\section{Acknowledgments}

Authors are thankful to the authorities of Quaid-e-Awam University of Engineering, Science and Technology Nawabshah, Pakistan for providing financial support and research facilities during this effort.

\section{References}

Abbas, Z., Harijan, K., Hameed, P., \& Bhayo, F. (2017). Effect of dust on the performance of photovoltaic system-a case study of Quaid-E-Azam Solar Park Bahawalpur, Pakistan. Noble International Journal of Scientific Research, 1(6), 3-79.

Akhmad, K., Kitamura, A., Yamamoto, F., Okamoto, H., Takakura, H., \& Hamakawa, Y. (1997). Outdoor performance of amorphous silicon and polycrystalline silicon PV modules. Solar Energy Materials and Solar Cells, 46(3), 209-218; https://doi.org/10.1016/S0927-0248(97)00003-2

Ali, H.M., Zafar, M.A., Bashir, M.A., Nasir, M.A., Ali, M., \& Siddiqui, A.M. (2017). Effect of dust deposition on the performance of photovoltaic modules in Taxila, Pakistan. Thermal Science, 21(2), 915-923; https://doi.org/10.2298/TSCI140515046A

Assoa, Y.B., Gaillard, L., Ménézo, C., Negri, N., \& Sauzedde, F. (2018). Dynamic prediction of a building integrated photovoltaic system thermal behaviour. Applied Energy, 214, 73-82; https://doi.org/10.1016/j.apenergy.2018.01.078

Bashir, M.A., Ali, H.M., Ali, M., \& Siddiqui, A.M. (2015). An experimental investigation of performance of photovoltaic modules in Pakistan. Thermal Science, 19(2), 525-534.

Bashir, M.A., Ali, H.M., Khalil, S., Ali, M., \& Siddiqui, A.M. (2014). Comparison of performance measurements of photovoltaic modules during winter months in Taxila, Pakistan. International Journal of Photoenergy, Article ID 898414, 1-8; http://dx.doi.org/10.1155/2014/898414

Cebecauer, T., Skoczek, A., \& Súri, M. (2011). The effect of solar radiation data types on calculation of tilted and sun tracking solar radiation. In $26^{\text {th }}$ European Photovoltaics Solar Energy Conference, 1-6.
Clean Energy Project Analysis (2004). RETScreen Engineering \& Cases Text Book- Photovoltaic Project Analysis, CANMET Energy Technology Centre, Canada, 1-46; www.retscreen.net.

Coskun, C., Toygar, U., Sarpdag, O., \& Oktay, Z. (2017). Sensitivity analysis of implicit correlations for photovoltaic module temperature: a review. Journal of Cleaner Production, 164 ,

1474-1485; https://doi.org/10.1016/j.jclepro.2017.07.080

Duffie, J.A., \& Beckman, W.A. (2013). Solar engineering of thermal processes, Fourth Edition, New York: Wiley.

Evans, D.L. (1981). Simplified method for predicting photovoltaic array outpu. Solar Energy, 27(6), 555-560; https://doi.org/10.1016/0038-092X(81)90051-7

Field, H., \& Gabor, A.M. (2002). Cell binning method analysis to minimize mismatch losses and performance variation in $\mathrm{Si}$ based modules. Twenty-Ninth IEEE Conference in Photovoltaic Specialists 418-421; DOI: 10.1109/PVSC.2002.1190548

Gaur, A., \& Tiwari, G.N. (2014). Performance of a-Si thin film PV modules with and without water flow: an experimental validation. Applied Energy, 128, 184-191; DOI: 10.1109/PVSC.2002.1190861

Harijan, K., Uqaili, M.A., \& Mirza, U.K. (2015). Assessment of solar PV power generation potential in Pakistan. Journal of Clean Energy Technologies, 3(1), 54-56.

Hasan, M.A., \& Sumathy, K. (2010). Photovoltaic thermal module concepts and their performance analysis: a review. Renewable and Sustainable Energy Reviews, 14, 1845-1859; https://doi.org/10.1016/j.rser.2010.03.011

Jakhrani, A.Q., Rigit, A.R.H., Baini, R., Samo, S.R., \& Ling, L.P. (2012). Investigation of solar photovoltaic module power output by various models. NED University Journal of Research, 25-35.

Jakhrani, A.Q., Samo, S.R., Kamboh, S.A., Labadin, J., \& Rigit, A.R.H. (2014). An improved mathematical model for computing power output of solar photovoltaic modules. International Journal of Photoenergy, Article ID 346704, 1-9; https://doi.org/10.1155/2014/346704

Jatoi, A.R., Samo, S.R., \& Jakhrani, A.Q. (2016). Influence of ambient temperature and solar radiations on photovoltaic module's temperature and power output. International Journal of Natural and Engineering Sciences, 10(2), 43-47.

Jatoi, A.R., Samo, S.R., \& Jakhrani, A.Q. (2018). Influence of temperature on electrical characteristics of different photovoltaic module technologies. International Journal of Renewable Energy Development, 7(2), 85-91; https://doi.org/10.14710/ijred.7.2.85-91

Jatoi, A.R., Samo, S.R., \& Jakhrani, A.Q. (2019). An improved empirical model for estimation of temperature effect on performance of photovoltaic modules. International Journal of Photoenergy, Article ID 1681353, 1-16; https://doi.org/10.1155/2019/1681353

Jatoi, A.R., Samo, S.R., \& Jakhrani, A.Q. (2019). Comparative study of the electrical characteristics of different photovoltaic modules in outdoor environment. Engineering, Technology \& Applied Science Research, 9(5), 4600-4604.

Kalogirou, S.A. (2014). Solar energy engineering: processes and systems, Amsterdam: Academic Press: Elsevier.

King, D.L., Boyson, W.E., \& Kratochvil, J.A. (2002) Analysis of factors influencing the annual energy production of photovoltaic systems, In Conference Record of the TwentyNinth IEEE Photovoltaic Specialists Conference, New Orleans, LA, USA, 1356-1361; DOI: 10.1109/PVSC.2002.1190861

Lee, W., Kim, Y., Wang, Y., Chang, N., Pedram, M., \& Han, S. (2011). Versatile high-fidelity photovoltaic module emulation system. In IEEE/ACM International Symposium on Low Power Electronics and Design, 91-96; 10.1109/ISLPED.2011.5993613

Maghami, M.R., Hizam, H., Gomes, C., Radzi, M.A., Rezadad, M.I. \& Hajighorbani, S. (2016). Power loss due to soiling on solar panel: a review. Renewable and Sustainable Energy 
Reviews,

59 , https://doi.org/10.1016/j.rser.2016.01.044

Malik, A.Q., Ming, L.C., Sheng, T.K., \& Blundell, M. (2010). Influence of temperature on the performance of photovoltaic polycrystalline silicon module in the Bruneian climate. ASEAN Journal on Science and Technology for Development, 27(2): 61-72.

Malik, P., \& Chandel, S.S. (2020). Performance enhancement of multi-crystalline silicon photovoltaic modules using mirror reflectors under western Himalayan climatic conditions. Renewable Energy, 154, 966-975; https://doi.org/10.1016/j.renene.2020.03.048

Mekhilef, S., Saidur, R., \& Kamalisarvestani, M. (2012). Effect of dust, humidity and air velocity on efficiency of photovoltaic cells. Renewable and Sustainable Energy Reviews, 16(5), 2920-2925; https://doi.org/10.1016/j.rser.2012.02.012

Milosavljević, D.D., Pavlović, T.M., \& Piršl, D.S. (2015). Performance analysis of a grid-connected solar PV plant in Niš, republic of Serbia. Renewable and Sustainable Energy Reviews, 44, 423-435; https://doi.org/10.1016/j.rser.2014.12.031

Perraki, V., \& Kounavis, P. (2016). Effect of temperature and radiation on the parameters of photovoltaic modules. Journal of Renewable and Sustainable Energy, 8(1), 0131021-11; https://doi.org/10.1063/1.4939561

Schwingshackl, C., Petitta, M., Wagner, J.E., Belluardo, G., Moser, D., Castelli, M., Zebisch, M., \& Tetzlaff, A. (2013). Wind effect on PV module temperature: Analysis of different techniques for an accurate estimation. Energy Procedia, 40, 77-86; https://doi.org/10.1016/j.egypro.2013.08.010

Shaari, S., Sopian, K., Amin, N., \& Kassim, M.N. (2009). The temperature dependence coefficients of amorphous silicon and crystalline photovoltaic modules using Malaysian field test investigation. American Journal of Applied Sciences, 6(4), 586-593.

Skoplaki, E., \& Palyvos, J.A. (2009). On the temperature dependence of photovoltaic module electrical performance: a review of efficiency / power correlations. Solar Energy, 83(5), 614-624; https://doi.org/10.1016/j.solener.2008.10.008

Technical brief (2017). The Effect of Irradiance and Temperature on the Performance of PV Modules. Sustainable Technologies Evaluation program (STEP), www.sustainabletechnologies.ca

Tripathi, A.K., Aruna, M., \& Murthy, S.N. (2017). Performance evaluation of PV panel under dusty condition. International Journal of Renewable Energy Development, 6(3), 225-233; https://doi.org/10.14710/ijred.6.3.225-233

Wilcox, S.M. (2012). National solar radiation database 1991-2010 update: user's manual, technical report no. NREL/TP-550054824", National Renewable Energy Laboratory, Golden, CO (United States) 1-479; https://www.nrel.gov/docs/fy 12osti/54824.pdf

Yusoff, N.F., Zakaria, Z., Zainuddin, H., \& Shaari, S. (2016). Operating temperature of photovoltaic module for retrofitted grid-connected photovoltaic system on metal roof. International Journal of Simulation: Systems, Science and Technology, 17, 541-545; DOI: 10.5013/IJSSST.a.17.41.54 